\title{
PEMBELAJARAN PJOK: MATERI KESEHATAN BERBASIS RISET
}

\author{
Susanto,M.Or ${ }^{4}$ \\ IAIN Tulungagung
}

"Pembelajaran berbasis riset (PBR) merupakan bagaian dari salah satu metode student-centered learning (SCL) dimana menggabungkan riset di dalam proses pembelajaran"

Pendidikan Jasmani Olahraga dan Kesehatan merupakan salah satu mata pelajaran wajib yang diajarkan pada sekolah-sekolah dari jenjang pendidikan anak usia dini hingga pendidikan menengah atas. Sebagai mata pelajaran wajib, pendidikan jasmani olahraga dan kesehatan bertujuan membentuk siswa yang memeliki pengetahuan belajar motorik, berkarakter sehat dan bugar. Salah satu materi didalam pembelajaran PJOK yaitu

${ }^{4}$ Susanto, M.Or. Lahir di Way Kanan 10 April 1984. Penulis adalah dosen Pendidikan Jasmani di IAIN Tulungagung. Mengampu mata kuliah Pendidikan Jasmani, Bermain, Olahraga kesehatan dan Gizi dan kesehatan pada prodi PIAUD dan prodi PGMI Fakultas Tarbiyah dan Ilmu Keguruan, Gelar Sarjana penulis dapatkan dari Fakultas Ilmu Keolahragaan UNY Yogyakarta tahun 2007. Sedangkan gelar Magister Olahraga dengan Konsentrasi Olahraga Anak Usia Dini penulis dapatkan dari PPs UNY Yogyakarta tahun 2013. Saat ini penulis sedang menempuh Program Doktor di PPs UNY pada Prodi Ilmu Pendidikan Konsentrasi Ilmu Keolahragaan. 
pendidikan kesehatan. Materi ini bertujuan memberikan wawasan kepada siswa agar lebih memahami dan peduli terkait bagaiman mengupayakan peningkatan derajat kesehatannya. Adapun sub materi kesehatan yang diajarkan disekolah diantaranya; budaya hidup sehat, meninggkatkan kebugaran, pengetahuan bahaya Narkoba, Alkohol, Rokok dan penyakit menular/tidak menular.

Pelayanan kesehatan pada dasarnya ada empat aspek, yaitu promotif, preventif, kuratif dan rehabilitatif. Empat aspek tersebut bersama-sama mempunyai fungsi dalam meningkatkan derajat status kesehatan Masyarakat. Pendidikan, merupakan salah satu sektor yang dapat diberikan amanah dalam mempromosikan kesehatan. Pada lini promotif, pendidikan kesehatan berperan mempunyai peranan yang dapat meningkatkan kesehatan seperti mengelola dan merencanakan gizi makan yang baik atau perencanaan sanitasi yang tepat. Pada lini preventif, melalui pendidikan kesehatan, masyarakat diharapkan melakukan upaya tindakan mengikuti program-program kesehatan dalam pencegahan penyakit seperti melakukan vaksinasi. Pada lini kuratif, masyarakat yang terdidik diharapkan memahami kondisi sakit sehingga mampu mempersiapkan dalam tindakan pengobatan. Yang terakhir, pendidikan dalam aspek rehabilitasi diharapkan dapat membuat masyarakat mengetahui bahwa perencanaan setelah mengalami masa penyembuhan perlu melakukan program rehabilitasi untuk mengembalikan keadaan semula. 
Materi Pendidikan kesehatan yang dilaksanakan di sekolah-sekolah merupakan bagian dari materi PJOK bertujuan mendukung aspek promosi kesehatan dan menitik beratkan pada perubahan perilaku. Dengan adanya pendidikan, diharapkan masyarakat mampu dan mau mengontrol perilakunya sehingga bisa meningkatkan derajat kesehatannya (Ottawa charter 1986, WHO). Deklarasi Jakarta pada tahun 1997 menjadikan bagian penting dalam peningkatan literasi kesehatan menegaskan peranannya pengetahuan pendidikan kesehatan. Pendidikan kesehatan tidak hanya saja dapat meningkatkan pengetahuan pendidikan kesehatan, namun lebih jauh bisa mengembangkan keterampilanketerampilan yang berguna bagi individu dan masyarakat (Nutbeam, 1998). Perubahan perilaku individu diharapkan dapat terjadi sebagai proses hasil dari pendidikan kesehatan. Pendidikan kesehatan merupakan kolaborasi beberapa bidang studi seperti psikologi, antropologi, sosiologi, pendidikan, komunikasi dan manajemen.

Banyak yang menanyakan mengenai apa yang dimaksud dengan pembelajaran berbasis riset? Pembelajaran berbasis riset (PBR) merupakan bagaian dari salah satu metode student-centered learning (SCL) dimana menggabungkan riset di dalam proses pembelajaran. (PUPBR, 2010). PBR memberi kesempatan kepada Mahasiswa untuk menggali informasi, menyusun hipotesis, mengumpulkan data, menganalisis data, dan membuat kesimpulan atas data yang sudah tersusun. Dalam proses ini pembelajaran dilakukan dengan pendekatan "learning by doing". Dengan PBR akan terbuka peluang bagi pengembangan metode pembelajaran, antara 
lain: (1) pembaruan bahan pembelajaran dengan mengkoneksikan hasil riset, (2) Peran aktif Mahasiswa di dalam pelaksanaan belajar riset, (3) pembelajaran dengan menggunakan instrumen riset, (4) pengembangan konteks riset secara inklusif. Berdasarkan paparan diatas, maka yang akan dibahas khusus pada tulisan ini yaitu pembaharuan pembelajaran dengan mengintegrasikan hasil riset, dan pembelajaran dengan menggunakan instrumen riset.

Seperti yang telah dijelaskan pada bagian sebelumnya, pendidikan kesehatan merupakan bagian dari solusi terhadap masalah-masalah kesehatan yang ada di masyarakat. Artinya, problem yang dimasukkan dalam kurikulum diharapkan sesuai dengan apa yang ada di masyarakat. Seperti apa yang menjadi masalah 10 tahun yang lalu, belum tentu masih menjadi masalah saat ini. Begitu juga sebaliknya, apa yang beberapa dekade lalu bukan merupakan suatu hal yang harus dirisaukan, bisa jadi sekarang ini merupakan problem yang harus dipikirkan jalan keluarnya secara serius.

Salah satu contoh yang dapat diambil misalnya merupakan problem penyakit tidak Menular, Kesehatan Jiwa, dan Kesehatan Gigi Mulut. Data Riskesdas 2018 menunjukkan prevalensi Penyakit Tidak Menular mengalami kenaikan jika dibandingkan dengan Riskesdas 2013, antara lain kanker, stroke, penyakit ginjal kronis, diabetes melitus, dan hipertensi. Prevalensi kanker naik dari 1,4 permil (Riskesdas 2013) menjadi 1,8 permil; prevalensi stroke naik dari 7 permil menjadi 10,9 permil; 
dan penyakit ginjal kronik naik dari 2 permil menjadi 3,8 permil. Berdasarkan pemeriksaan gula darah, diabetes melitus naik dari 6,9\% menjadi 8,5\%; dan hasil pengukuran tekanan darah, hipertensi naik dari 25,8\% menjadi $34,1 \%$. Kenaikan prevalensi penyakit tidak menular ini berhubungan dengan pola hidup, antara lain merokok, konsumsi minuman beralkohol, aktivitas fisik, serta konsumsi buah dan sayur. Sejak tahun 2013 prevalensi merokok pada remaja (10-18 tahun) terus meningkat, yaitu 7,2\% (Riskesdas 2013), 8,8\% (Sirkesnas 2016) dan 9,1\% (Riskesdas 2018). Data proporsi konsumsi minuman beralkohol pun meningkat dari 3\% menjadi 3,3\%. Demikian juga proporsi aktivitas fisik kurang juga naik dari $26,1 \%$ menjadi $33,5 \%$ dan $0,8 \%$ mengonsumsi minuman beralkohol berlebihan. Hal lainnya adalah proporsi konsumsi buah dan sayur kurang pada penduduk $\geq 5$ tahun, masih sangat bermasalah yaitu sebesar 95,5\%. Peningkatan proporsi gangguan jiwa pada data yang didapatkan Riskesdas 2018 cukup signifikan jika dibandingkan dengan Riskesdas 2013, naik dari 1,7 permil menjadi 7 permil. Untuk kesehatan gigi dan mulut, Riskesdas 2018 mencatat proporsi masalah gigi dan mulut sebesar $57,6 \%$ dan yang mendapatkan pelayanan dari tenaga medis gigi sebesar 10,2\%. Adapun proporsi perilaku menyikat gigi dengan benar sebesar 2,8\%.

Permasalah kesehatan lain yang juga tidak kalah pentingnya adalah status Gizi. Riskesdas 2018 menunjukkan adanya perbaikan status gizi pada balita di Indonesia. Proporsi status gizi sangat pendek dan pendek turun dari 37,2\% (Riskesdas 2013) menjadi 30,8\%. Demikian juga proporsi status gizi buruk dan gizi kurang 
turun dari 19,6\% (Riskesdas 2013) menjadi 17,7\%. Namun yang perlu menjadi perhatian adalah adanya tren peningkatan proporsi obesitas pada orang dewasa sejak tahun 2007 sebagai berikut 10,5\% (Riskesdas 2007), 14,8\% (Riskesdas 2013) dan 21,8\% (Riskesdas 2018).

Terdapat beberapa strategi dalam memadukan pembelajaran dan riset yang secara empirik dikembangkan pada Griffith University yaitu :

1. Memperkaya sumber bahan ajar dengan memanfaatkan hasil penelitian guru.

2. Mencari berbagi temuan penelitian dan melacak sejarah ditemukannya perkembangan mutakhir tersebut.

3. Memperkaya kegiatan pembelajaran dengan menambahkannya isu-isu penelitian.

4. Mengajarkan materi terkait metodologi penelitian di dalam proses pembelajaran.

5. Memperkaya dalam proses pembelajaran dengan cara melakuakan kegiatan penelitian dalam skala kecil.

6. Memperkaya proses pembelajaran dengan cara melibatkan peserta didik dalam kegiatan penelitian institusi.

7. Memperkaya proses pembelajaran dengan cara mendorong peserta didik supaya mereka merasa menjadi bagian dari budaya penelitian.

8. Memperkaya proses pembelajaran dengan memasukkan nilai-nilai yang diperlukan oleh peneliti. 
Dapat juga dipertimbangkan akibat-yang akan terjadi penelitian lintas sektor yang dapat turut menunjang keberhasilan pembelajaran pendidikan kesehatan. menjadi contoh, adanya pengaruh kultur pada pelaksanaan program hegemoni kesehatan (Collins et all, 2014). pada dalam penelitian itu, ternyata cacat yg bekerjasama dengan obesitas, Human Immunideficiency Virus (HIV) serta Acquired Immune Deficiency Syndrome (AIDS) tidak terlepas dari kultur yg diterima pada suatu daerah. pada daerah tertentu, dikatakan adanya kultur memiliki porsi makan yg besar serta semakin tergerusnya kawasan membeli makan yg sehat pada lingkungan perumahan membuat semakin sulit buat menurunkan nomor obesitas. (Airhihenbuwa, 2010), Morland, Wing \&diez Rouz, 2002). Selain itu, dalam satu dasa warsa terakhir telah banyak akibat penelitian yang berkata betapa stigma sudah turut serta dalam penyebaran, deteksi, dan penatalaksanaan infeksi HIV.(Herek et all,2003, Kinsler et all 2007, Petros et all 2006, Poindexter 2010). stigma didiskusikan sebagai bagian berasal komponen dan proses yang terhubung menggunakan nilai-nilai normatif (Link \&Phelan (2006). Lebih lanjut, kultur juga sebagai bagian krusial dalam penyusunan kurikulum berbasis riset (Lipka, J et all, 2005, Nijhuis.C.J.G,2013).

Implementasi praktek berbasis riset pada beberapa profesi telah dilakukan dimulai tahun 1990an, seperti misalnya pada profesi kedokteran serta psikologi. Penerapan yang akan terjadi riset didalam bidang pendidikan sendiri bisa dikatakan tertinggal (Hempenstall, 2006). Belajar dari negara lain, Indonesia dapat memulai dengan cara mempertinggi kepedulian terhadap 
pendidikan kesehatan berbasis riset, serta membentuk gerakan yang dibutuhkan bisa membawa perubahan yang memberikan hasil signifikan.

Di Inggris, kekhawatiran yang sama akhirnya membentuk strategi Literasi Nasional / National Literacy Strategy (Departement for Education and Employment, 1998) yang menyampaikan mandat bahwa pendekatanpendekatan pedagogi harus berdasarkan yang akan terjadi riset. pada awal pelaksanaannya, dekrit ini menerima penolakan berasal global pendidikan serta tujuan yg direncanakan tidak tercapai. Pendekatan baru lalu dilegalkan menjadi Primary National Strategy di tahun 2006.

Di era digital saat ini, ada banyak media yang dapat dimanfaatkan untuk menghimpun berbagai informasi dan menyebarkannya pada seluruh pihak yang berkecimpung didalamnya, yaitu internet. salah satu model yang bisa dicermati artinya ectacenter.org. Website ini berada pada bawah pengelolaan University of North Carolina, serta menyediakan infrormasi bagi pelaksanaan praktik pendidikan berbasis riset dibidang pendidikan anak usia dini. Pada halaman website tadi terdapat berita mulai dari definisi mengenai praktik pendidikan berbasis bukti, sistem pembelajaran, implementasi, sampai dengan yang akan terjadi-hasil penelitian terbaru yang dapat mendukung aplikasi praktik pendidikan berbasis riset. Hal ini sangat beguna jika dilakukan pada Indonesia, mengingat negara Indonesia mempunyai daerah yang luas dan masih terdapat kendala trasportasi di beberapa wilayah. Dengan adanya panduan seperti ini, maka 
siapapun dari asal manapun bisa mengakses informasi, sehingga diharapkan bisa mempercepat pelaksanaan praktik pendidikan berbasis riset.

Hal terakhir yang paling krusial ialah mempersiapkan para pendidik agar dapat melakukan praktik pendidikan berbasis bukti. Pendidikan terbagi sebagai 2, yaitu pendidikan di institusi perguruan tinggi, serta pendidikan berkelanjutan. Perkuliahan dirancang dan dibuat agar dapat mengajarkan seni manajemen belajar yang efektif. Salah satu model pembelajaran ialah penelitian yang dilakukan Slameto dkk di tahun 2016. Penelitian ini berhasil menemukan model Pembelajaran Berbasis Riset di Prodi Pendidikan guru Sekolah Dasar yang dinilai layak dan mampu menaikkan akibat belajar mahasiswa. (Slameto, dkk . 2016). Selain itu, pendidikan berkelanjutan perlu juga diberikan pagi para pendidik agar mereka tetap mendapat akibat-akibat riset terkini yang dapat diaplikasikan pada praktek pedagogi di dalam kelas.

Implementasi pembelajaran Pendidikan Jasmani Olahraga dan Kesehatan pada meteri sub kesehatan berbasis riset di Indonesia memang masih berada dalam tahap awal. Keberhasilannya tergantung berasal dari berbagai pihak, yang bisa dilakukan ketika ini merupakan komitmen dari institusi pencetak pendidik memulai memasukkan unsur riset serta sekaligus membekali para mahasiswa dengan kemampuan menganalisa, memilih serta menggunakan yang akan terjadi- hasil riset yang sesuai, dan juga komitmen pemerintah dalam bentuk pendanaan riset. 


\section{DAFTAR PUSTAKA}

Airhihenbuwa.C.O (2010). Culture Matters in Global Health. European Health Psychologist. 12,52-55

Deklarasi Jakarta tentang Promosi Kesehatan pada Abad 21(Online) Diungguh dari http://perpustakaan.litbang.depkes.go.id/otomasi /index.php? $\mathrm{p}=$ show_detail\&id=5781

Herek, G.M, Capitano,J.P \& Widaman, K.F (2003). Stigma, social risk and health policy: Public attitudes toward HIV surveillance policies and the social construction of illness. Health Psychology, 22, 533540.

Kinsler,J.J., Wong,M.D., Sayles,J.N..,Davis,C., \& Cunningham, W.E.(2007). The effect of perceived stigma from a health care provider on access to care among a low income HIV-positive population. AIDS Patient Care STDS, 21,584-592.

Lipka, J. et all (2005). The Relevance of Culturally Based Curriculum and Instruction: The Case of Nancy Sharp. Journal of American Indian Education Volume 44, Issue 3,31-54

Link, B. G., \& Phelan, J. C. (2006). Stigma and its public health implications. Lancet, 367, 528-529.

Morland,K. Wing,S., \& Diez Roux,A. (2002). The Contextual effect of the local food environment on residents diet: The atherosclerosis risk in community study. American Journal of Public Health,92,1761-1767 
Nijhuis, C.J.G (2013). Influence of culture on curriculum development in Ghana: an undervalued factor?. Journal of Curricullum Studies. Volume 45, 2013. Issue 2.

Nutbeam D (1998) Health promotion glossary. Health Promotion International: V 0113. no. 4. Oxford University Press.

Pedoman Umum Pembelajaran Berbasis Riset (PUPBR). Universitas Gajah Mada. 2010.

Petros, G., Airhihenbuwa,C.O., Simbayi, L.,Ramlagan,S.,\& Brown,B.(2006). HIV positive women: Perceptions of stigma in healthcare settingin Western Cape, South Africa. Healthcare for Women International. Advance online publication. Doi:10.1080/07399332.2012.736566

Poindexter, C. C., \& Shippy, R. A. (2010). HIV diagnosis disclosure: Stigma management and stigma resistance. Journal of Gerontological Social Work, $53,366-381$.

Pulgaron. E. Childhood Obesity: A Review of Increased Risk for Physical and Psychological Comorbidities. Clin Ther. 2013 January ; 35(1): A18A32

Riset Kesehatan Dasar 2018 (Riskesdas 2013), (Online) Diunduh dari http://sehatnegeriku.kemkes.go.id/baca/rilismedia/20181102/0328464/potret-sehatindonesia-riskesdas-2018/ 
Slameto, Wardani,N.S; Kristin,F. Pengembangan Model Pembelajaran Berbasis Riset Untuk Meningkatkan Keterampilan Berpikir Aras Tinggi. Prosiding Konser Karya Ilmiah Nasional Vol. 2, Agustus 2016 | ISSN: 2460-5506

Soegondo, Sidartawan. Berbagai Penyakit dan Dampaknya terhadap Kesehatan dan Ekonomi. Widyakarya Nasional Pangan dan Gizi (WNPG) IX. Jakarta, 2008.

The Ottawa Charter for Health Promotion 1986. (Online) Diungguh dari http://www.who.int/healthpromotion/conferenc es/previous/ottawa/en/index4.html

Walter C. Willett, Jeffrey P. Koplan, Rachel Nugent, Courtenay Dusenbury, Pekka Puska, and Thomas 